\title{
Electoral Behavior in Sub-Saharan Africa: Explanatory Factors and Implications: An Exploratory Study
}

\author{
Nga Nkouma Tsanga Rosalie Christiane \\ University of Maroua, Maroua, Cameroun
}

\begin{abstract}
The aim of this research is to identify the factors that determine the voting behaviors of African populations in a context of strong competition between different political products. To do this, a synoptic review of concepts involved is first presented. Then, 60 semi-directive interviews were conducted with persons who have the voter cards and who participated in the vote during the last two presidential and legislative elections in order to identify the factors that influenced their decision. A content analysis of the interviewees' speeches reveals that four categories of factors determine the electoral behavior of Cameroonians: candidate profile, socio economic, political and situational factors.
\end{abstract}

Keywords: political marketing, electoral behavior, influence factors, vote, multiparty elections

\section{Introduction}

The last two decades have been marked in Sub-Saharan Africa by the democratization of wind, generating a proliferation of opposition parties and animating the full populations of hope of freedom to choice candidates in this context of competitiveness. Thus, in this period, many of the ruling elites of Africa have been able to integrate the need for political legitimacy through popular vote in multiparty elections. This trend toward the institutionalization of democratic politics in competition in Sub-Saharan Africa draws our attention and leads us to make a study of electoral behavior of Cameroonians consumer.

Electoral behavior means all personal electoral activities, including participation in election campaigns, turnout of the pools, and choice of a candidate (Bratton, 2013). Three schools of thought can flow from this concept: sociological current (Lazarsfeld \& Al, 1944; Lipset, 1960), rational choice perspectives (Downs, 1957; Fiorina, 1981), and psychological current (Erdmann, 2007).

Electoral behavior appears to be influenced by economics factors (Lewis-Beck \& Stegmaier, 2000; Dubois, 2007), institutional factors (Dubois, 2007), political factors (Dubois, 2007; Lewis-Beck, 2005), situational factors (Dubois, 2007), and personal variables of voter and candidate (Michelat \& Simon, 1989; Dubois, 2007; Akhter \& Sheikh, 2014; Shin, 2017).

Today, after these upheavals we are entitled to ask ourselves what determines the electoral behavior of Cameroonians voter. Reasons such as the characteristics and the achievements of the applicants, the institutional framework of the vote influence their decisions choice? Or their electoral behavior is simply

\footnotetext{
Nga Nkouma Tsanga Rosalie Christiane, Ph. D., lecturer, Department of Marketing Trade Selling, Faculty of Economics and Management Sciences, University of Maroua, Maroua, Cameroun.

Correspondence concerning this article should be addressed to Nga Nkouma Tsanga Rosalie Christiane, Doursoungo-Maroua, PO Box 416, Maroua, Cameroun.
} 
related to their socio demographic and psychological profiles, the gifts of the candidate, their political affiliation, religious, ethnic, or familial links? There are questions which this exploratory study proposes to answer. For this, after a literature review of the concepts mentioned, we will interview the people concerned by the vote to inquire the factors that influenced their behavior.

\section{Literature Review}

Three theoretical approaches have been used in literature to explain electoral behavior: the sociological approach, the rational choice perspectives, and the psychological approach. These different currents of thought will lead us towards the influence factors.

\section{Theoretical Approaches of Electoral Behavior}

Electoral behavior can be divided into three schools of thought: the sociological, psychological, and political approaches.

\section{Sociological approach or Columbia School}

According to this perspective, electoral behavior is both influenced by socio economics and socio cultural factors. Thus, socio economics characteristics, religion, social classes are predictive factors of voter's choice.

\section{Psychological approach or Michigan School}

This School of thought has developed three variables as explanatory factors of electoral behavior: party identification, candidate orientations, and issue orientations. Party identification refers to the voter psychological attachment to a political party. While candidate orientation means his efficacy, capacities, and his personal qualities like his morality, his dynamism, his pious character, etc. And issue orientation concerns the attitude of the voter towards the performance of candidate staff: what the candidate staff should do or should not do. In sum, party identification determines the evaluation of candidate, issues, and the capacity of party to solve the problems of populations.

\section{Rationality's choice approach}

According to this approach, citizens act rationally in politics as in economics. Thus, they may adopt egotropic or sociotropic behavior. In the first case the voter evaluates the economic performance of candidate from the personal point of view while in the second case he evaluates the impact of these performances from the point of view of the whole society. It is a matter of answering two fundamental questions: What does it bring to me? What does it bring to society?

Although many empirical studies have been carried out to support these theories, it nevertheless remains that other factors related to culture aspects, context, corruption may influence the voter choice in Sub-Saharan African.

Finally, we think that five types of variables are susceptible to influence electoral behavior: socio economic factors, political factors, situational factors, candidate profile, and voter socio demographics variables.

\section{Determinants of Electoral Behavior}

Several endogenous and exogenous motives can justify electoral behavior. Endogenous factors related to voter and exogenous depend on situational, political, economic factors, etc.

\section{Endogenous factors}

Electoral behavior depends on the socio-demographic profiles of the voter especially: gender, generation, 
ethnic, and income.

- Gender has always been a determinant factor of voter choice and many works prove this thought (Ekstrand \& Eckert 1981; Rosenwasser \& Al, 1988; Campbell \& Heath, 2017);

- Generation: electoral behavior also depends on age/generation (Marsh, 2007; Goerres , 2007);

- Ethnic/dialect and cultural affiliation are also very important determinant of voter choice in African context (Conroy-Krutz, 2013; Lindberg \& Minion, 2008);

- Income: the role of income is a determinant factor of electoral behavior in Africa (Akhter \& Sheikh, 2014; Banerjee \& Chaudhuri, 2016) because candidates "buy" voter with gifts and money. The fact that Sub-Saharan African countries are poor and therefore that the majority of population has a low income or does not have an income which favorises the phenomena of corruption.

\section{Exogenous factors}

Others variables like socio economic factors, political factors, situational factors, and candidate profile influence voter decision.

- Socio economic factors: voters seem concerned about a retrospective or prospective vote (Dubois, 2007). So if former candidate has made it possible to improve the economic aggregates they will continue to vote him or if the new candidate promises a better future (reduction of unemployment, etc), they will give him their voices;

- Political and institutional factors (Dubois, 2007; Lewis-Beck, 2005); the turnout also depends on many factors like nature of election, party popularity, mobilization of political parties, electoral system, and operating procedures;

- Situational factors have been another factor of electoral behavior. Several studies show that the timing or context of election (Dubois, 2007; Akhter \& Sheikh, 2014), illiteracy in some heavily populated areas (Akhter $\&$ Sheikh, 2014) and the campaign spending (F. Palda \& K. Palda, 1998) influence the voter decision;

- Candidate profile (Dubois, 2007): The characteristics of the candidate can also guide the voter choice. It can be about his origin, his dialect, personality, his political party, ideology, his political program, his curriculum, his experience in administration/politic, and the number of mandate.

The theoretical bases being laid, we will now turn to the voters in order to identify the factors that influenced their choice decisions.

\section{Research Method}

The author chooses Cameroon for this study because it is one of the countries in Sub-Saharan Africa which is a proliferation of political parties. Last year, there were 300 political parties approximately legalized.

\section{Methodology}

The objective of this study being to determine the factors that influence electoral behaviours, a qualitative approach seems relevant through the use of individual interviews which allows us to collect the maximum of information on the subject.

Thus, semi-directed interviews were conducted with 60 Cameroonians whose ages ranged between 23 and 60 years. A filter was made in order to retain only those persons who participated in at least two elections, including a presidential one. The characteristics of those respondents are summarized in the table below. 
Table 1

Respondents’ Socio Demographic Characteristics

\begin{tabular}{|c|c|c|c|}
\hline Characteristics & & $\mathrm{N}$ & $\%$ \\
\hline \multirow{2}{*}{ Gender } & Male & 28 & 46.67 \\
\hline & Female & 32 & 53.33 \\
\hline \multirow{4}{*}{ Age } & 23 to 30 years old & 13 & 21.67 \\
\hline & 30 to 40 years old & 10 & 16.67 \\
\hline & 40 to 50 years old & 22 & 36.66 \\
\hline & 50 to 60 years old & 15 & 25 \\
\hline \multirow{4}{*}{ Marital status } & Single & 19 & 31.66 \\
\hline & Married & 24 & 40 \\
\hline & Divorced & 10 & 16.67 \\
\hline & Widow & 07 & 11.67 \\
\hline \multirow{4}{*}{ Religion } & Catholic & 28 & 46.67 \\
\hline & Protestant & 17 & 28.33 \\
\hline & Muslim & 10 & 16.66 \\
\hline & Other & 05 & 08.34 \\
\hline \multirow{4}{*}{ Level of studies } & No level & 8 & 13.33 \\
\hline & Primary & 12 & 20 \\
\hline & Secondary & 25 & 41.67 \\
\hline & University & 12 & 25 \\
\hline \multirow{5}{*}{ Income } & No income & 12 & 20 \\
\hline & Less than 100,000 & 18 & 30 \\
\hline & 100,000 to 200,000 & 09 & 15 \\
\hline & 200,000 to 300,000 & 11 & 18.33 \\
\hline & More than 300,000 & 10 & 16.67 \\
\hline Total & & 60 & \\
\hline
\end{tabular}

The interviews lasted 45 minutes to one hour and they concerned three aspects: the participation of electoral activities, the motivations of voter choice, the voter profile, and the relationship between the candidate and the voter.

The semi-directed interviews carried out during our study are completely recorded, then retranscribed. An analysis of contents is then done on the basis of verbatim obtained while being based on the method of open coding. Indeed, this method enabled us to locate "sub-themes" in the text which were then analysed manually.

\section{Results and discussion}

The results of this study reveal that electoral behaviour is both influenced by endogenous and exogenous variables.

\section{Presentation of Results}

The table below summarizes the determinants of choice of ecological packaging with regard to the respondents. 
Table 2

Factors That Influence of Electoral Behaviors in Cameroon

\begin{tabular}{|c|c|c|c|c|}
\hline Themes & Sub-themes & Frequency & Glossary & Verbatim \\
\hline \multirow{3}{*}{$\begin{array}{l}\text { Endogenous } \\
\text { factors of electoral } \\
\text { behavior }\end{array}$} & \multirow{3}{*}{$\begin{array}{l}\text { Socio } \\
\text { demographic } \\
\text { characteristics } \\
\text { of voter }\end{array}$} & $\begin{array}{l}\mathrm{N}=28 \\
\mathrm{~N}=22\end{array}$ & Gender & $\begin{array}{l}\text { "It is difficult for me to vote a woman" } \\
\text { "I am a woman but I cannot vote a woman" }\end{array}$ \\
\hline & & $\begin{array}{l}N=7 \\
N=32 \\
N=11\end{array}$ & $\begin{array}{l}\text { Illeterate } \\
\text { Educated } \\
\text { intellectual }\end{array}$ & $\begin{array}{l}\text { "I vote the one who gives me gifts" } \\
\text { "I vote the one you can provide employment and } \\
\text { reduce unemployment" } \\
\text { "I vote the one who has a good political program" }\end{array}$ \\
\hline & & $\begin{array}{l}\mathrm{N}=12 \\
\mathrm{~N}=50\end{array}$ & $\begin{array}{l}\text { Without pay } \\
\text { Salaried }\end{array}$ & $\begin{array}{l}\text { "If he wants me to vote him, he must give me } \\
\text { something" } \\
\text { "I vote the one that will improve the economic } \\
\text { situation and preserve peace" }\end{array}$ \\
\hline \multirow{15}{*}{$\begin{array}{l}\text { Exogenous factors } \\
\text { of electoral behavior }\end{array}$} & \multirow[t]{2}{*}{ Political factors } & $\begin{array}{l}\mathrm{N}=49 \\
\mathrm{~N}=25\end{array}$ & Nature of election & $\begin{array}{l}\text { "I can't miss presidential election" } \\
\text { "Presidential election is the most important in the } \\
\text { nation" } \\
\text { "Legislative election is very important" }\end{array}$ \\
\hline & & $\mathrm{N}=48$ & $\begin{array}{l}\text { Image of the ruling } \\
\text { party }\end{array}$ & $\begin{array}{l}\text { "The party in power seems serious and I prefer it" } \\
\text { "Those opponents are disorganized and hungry" }\end{array}$ \\
\hline & \multirow{3}{*}{$\begin{array}{l}\text { Socio economic } \\
\text { factors }\end{array}$} & $\mathrm{N}=51$ & $\begin{array}{l}\text { Amelioration of } \\
\text { economic aggregates }\end{array}$ & "A candidate that will get us out of crisis" \\
\hline & & $\mathrm{N}=52$ & $\begin{array}{l}\text { Improvement of } \\
\text { daily life }\end{array}$ & "I vote the candidate who will improve my daily life" \\
\hline & & $\mathrm{N}=45$ & $\begin{array}{l}\text { Development of } \\
\text { localities }\end{array}$ & $\begin{array}{l}\text { "I will vote the one who can develop my } \\
\text { village/region" }\end{array}$ \\
\hline & \multirow{3}{*}{$\begin{array}{l}\text { Situational } \\
\text { factors }\end{array}$} & $\mathrm{N}=34$ & Context of election & "I will vote a candidate that will improve things" \\
\hline & & $\mathrm{N}=48$ & Campaign message & $\begin{array}{l}\text { "I will vote a candidate that promises good } \\
\text { educational and health policies" }\end{array}$ \\
\hline & & $\mathrm{N}=39$ & $\begin{array}{l}\text { Fight against } \\
\text { corruption }\end{array}$ & $\begin{array}{l}\text { "I will vote a candidate who will put an end to this } \\
\text { corruption gangrene" }\end{array}$ \\
\hline & \multirow{7}{*}{$\begin{array}{l}\text { Candidate } \\
\text { profile }\end{array}$} & $\mathrm{N}=37$ & Gender & "Women are not made to govern" \\
\hline & & $\mathrm{N}=28$ & Age & "Power is not for children" \\
\hline & & $\mathrm{N}=31$ & Marital status & $\begin{array}{l}\text { "Voting a bachelor is to entrust the country to an } \\
\text { adventurer" }\end{array}$ \\
\hline & & $N=46$ & $\begin{array}{l}\text { Experience of } \\
\text { candidate }\end{array}$ & "The country needs people who have the expert" \\
\hline & & $\mathrm{N}=34$ & Political party & "I prefer to vote the candidate of the ruling party" \\
\hline & & $\mathrm{N}=43$ & Religious affiliation & "Everything except the awakened churches in power" \\
\hline & & $\mathrm{N}=35$ & Ethny & $\begin{array}{l}\text { "I prefer to vote someone from home" } \\
\text { "Imagine a ...on the head of this country? Very bad" }\end{array}$ \\
\hline
\end{tabular}

\section{Discussion}

The analysis of the speech obtained shows that four dimensions, with 18 items, determine the electoral behavior of Cameroonians: socio economic dimension, political dimension, situational dimension, and candidate profile. These results also reveal that the most important factors that influence voter's choice are the capacity of regime to improvement of daily life (cited 52/60 times) and to ameliorate economic aggregates (cited 51/60), the preservation of peace (50/60), the nature of election (49/60), the image of the ruling party (48/60), the campaign message (48/60), the experience of candidate (46/60), the development of localities $(45 / 60)$, and the religious affiliation of candidate $(43 / 60)$. 
The reading of these results makes it possible to identify two types of electoral behavior: egotropic and sociotropic behaviors. Indeed, it emerges from the interviews realized that some wish to obtain gifts from the candidates ("If he wants me to vote him, he must give me something", Albert, unemployed young, 24 years old) or to see their daily improve ("I vote the candidate who will improve my daily life", Mary, accountant, 35 years old) while others wish to see their locality developed and economic aggregates improved. This research also underlines the importance of immaterial aspects like the fight against corruption, peace, and culture.

\section{Conclusion}

The aim of this research was to identify the factors that determine the electoral behavior of African in context on multiparty and poverty. The exploratory study conducted in Cameroon shows that the electoral behavior is influenced by candidate profile, socio economic, political and situational variables.

Knowledge of the dimensions of electoral is as important for researchers as for political actors. This study made it possible to highlight variables that can measure the phenomenon posed and should be extended by a quantitative study on a large sample in order to better understand the choice of candidate by a voter. For political actors, it will be question of proposing a political offer that integrates these variables in order to gain the confidence of voters and be more competitive than their competitors.

\section{References}

Akhter, Z., \& Sheikh, Y. A. (2014). Determinants of voting behavior in India: Theoretical perspective. Public Policy and Administration Research, 4(8), 104-108.

Banerjee, S., \& Chaudhuri, B. R. (2016). Influence of voter demographic and newspaper in shaping political party choice in India: An empirical investigation. Journal of Political Marketing, 19(1), 1-28.

Bratton, M. (2013). Voting and democratic citizenship in Africa. Lynne Rienner Publishers.

Campbell, R., \& Hearh, O. (2017). Do women vote women? Attitude toward descriptive and representation and voting behavior in 2010 British election. Politics \& Gender, 13(2), 209-231.

Cronroy-Krutz, J. (2013). Information and ethnic politics in Africa. British Journal of Political Science, 43(2), 345-373.

Downs, A. (1957). An economic theory of political action in democracy. Journal of Political Economy, 65, 135-150.

Dubois, E. (2007). Les déterminants économiques du vote 1976-2006: trente ans de fonctions de vote en France. Revue d'Economie Politique, 117(2), 243-270.

Ekstrand, L. E., \& Eckert, W. A. (1981). The impact of candidate's sex on voter choice. The Western Political Quaterly, 34(1), 78-87. Erdmann, G. (2007). Ethnicity, voter alignment and political party affiliation in Africa case: Zambia. GIGA Working Paper 45. Hamburg Institute of Global Area Studies.

Fiorina, M. P. (1981). Retrospective voting in America national elections. Yale University Press.

Goerres, A. (2007). Why are older people more likely to vote? The impact of ageing on electoral turnout in Europe. British Journal of Politics and International Relations, 9(1), 90-121

Lazarsfeld, P. F., \& Al. (1944). The people choice. New York: Columbia University Press.

Lewis-Beck, M. S., \& Stegmaier, M. (2000). Economic determinants of electoral outcomes. Annual Review of Political Science, 3(1), 183-219.

Lewis-Beck, M. S. (2005). Election forecasting: Principles and practice. British Journal of Politics and International Relations, 7 , 145-164.

Lindberg, S., \& Minion, M. (2008). Are African voters really ethnic or clientelistic? Survey evidence from Ghana. Political Science Quaterly, 123(1), 95-122.

Lipset, S. M. (1960). Political man: The social bases of politics. New York: Doubleday.

Marsh, M. (2002). Electoral context. Electoral Studies, 21(2), June, 207-217.

Michelat, G., \& Simon, M. (1989). Chapitre 11. Religion, classe sociale, patrimoine et comportement électoral: l'importance de la dimension symbolique. In Daniel Gaxie, Explication du vote, Presses de Sciences Po (P.F.N.S.P.), 'Références', 2è édition, 291-322. 
Palda, F., \& Palda, K. (1998). The impact of campaign expenditures on political competition in the French legislative elections of 1993. Public choice, 94, 157-174.

Rosenwasser, S. M., \& Seale, J. (1988). Attitudes toward a hypothetical male or female presidential candidate: A research note. Political Psychology, 9(4), Dec., 591-598.

Shin, J. H. (2017). The choice of candidate-centered electoral systems in new democracies. Party Politics, 23(2), $160-171$.

Van Der Brug, W., \& Kritzinger, S. (2012). Generational differences in electoral behaviour. Electoral Studies, 31(2), $245-249$. 